\title{
ОРТОПЕДИЧНИЙ РОЗДІЛ
}

УДК 616.314-089.23-071

DOI https://doi.org/10.35220/2523-420X/2019.1.7

*П. В. Іиценко, к. мед. н., Борисенко А. В. , д. мед. н.

*Донецький Національний медичний університет МОЗ України

Національний медичний університет ім. О.О. Богомольця

Актуальність. Проблема захворювань пародонту займає великий відсоток серед стоматологічних захворювань,щзо спонукає лікарів науковиів та стоматологів практиків більш активно займатися даною патологією. Ортопедичне втручання дуже важливе при функціональному відновленні иілісності зубного ряду у пацієнтів без дефектів зубного ряду з генералізованим пародонтитом у стадіі стабілізації.

Нами для лікування генералізованого пародонтиту з боку ортопедичної складової запропоновані заявлені інтердентальні иини, які використовувались при ортопедичному лікуванні пацієнтів з даною патологією поряд з традийійним иинуванням.

Мета З'ясувати клінічно, які з використаних у дослідженні шин більш фізіологічні для спровокованого пародонту в зоні їх відповідальності за допомогою $І Г$.

Матеріали та методи Дане клінічне дослідження проведене на групі з 54 хворих генералізованим пародонтитом, у стадії стабілізації. Попередньо їм було проведено комплексне лікування генералізованого пародонтита. У досліджуваній групі зі станом пародонта в стадії стабілізації перебувало 24 людини. Це група із заявленими досліджуваними шинами. І група із шинами відомими традиційними - у кількості 30 людей у групі.

Результати При проведенні дослідження встановлено, щз через 18 місяиів значення показника індексу гі-

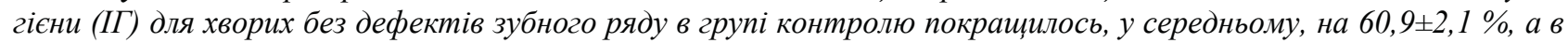

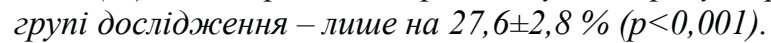

За весь період дослідження в групі без дефектів зубного ряду динаміка розвитку ознак прочесу запалення в досліджуваній групі більш стримана в порівнянні з контролем, щяо говорить про доцільність застосування заявлених конструкиій в даній групі.

Висновки. Проведені дослідження у групах пацієнтів виявили перевагу в застосувнні нових шинуючих конструкиій при застосуванні їх при генералізованому пародонтиті у стадії стабілізації перед традиційним

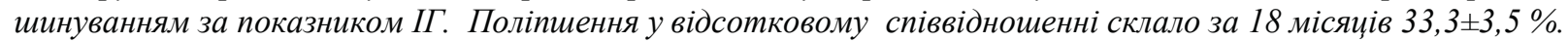

Ключові слова: генералізований пародонтит у стадії стабілізації, ІГ, інтердентальне шинування.

\section{*П.В.Ищенко, А.В.Борисенко}

*Донецкий Национальный медицинский университет МОЗ Украины Национальный медицинский университет им. А.А. Богомольца

\section{АНАЛИЗ РЕЗУЛЬТАТОВ ПРИМЕНЕНИЯ ЗАЯВЛЕННЫХ И ТРАДИЦИОННЫХ НЕСЪЕМНЫХ ШИНИРУЮЩИХ ОРТОПЕДИЧЕСКИХ КОНСТРУКЦИЙ У ПАЦИЕНТОВ БЕЗ ДЕФЕКТА ЗУБНОГО Р ЯДА, ИМЕЮЩИХ ГЕНЕРАЛИЗОВАННЫЙ ПАРОДОНТИТ В СТАДИИ СТАБИЛИЗАЦИИ ПО ПОКАЗАТЕЛЮ ИГ}

Актуальность. Проблема заболиваний пародонта занимает большой процент среди стоматологических заболеваний, которая побуждает врачей - научных работников и стоматологов- практиков более активно заниматься данной патологией. Ортопедчческое вмешательство очень важно при функииональном восстановлении цеелостности зубного ряда у паџиентов без дефектов зубного ряда с генерализованным пародонтитом в стадии стабилизации.

Нами для лечения генерализованного пародонтита со стороны ортопедической составляющей предложены заявленные интердентальные иины, которые использовались при ортопедчческом лечении пациентов с данной патологией наряду с традиционным шинированием.

Цель. Выяснить клинически, какие из применяемых в исследовании иин более физиологичны для спровоцированного пародонта в зоне их ответственности с помощьью показателей ИГ.

Материалы и методы. Данное клиническое исследование проведено на группе из 54 больных генерализованным пародонтитом, в стадии стабилизации. Предварительно им было проведено комплексное лечение генерализованого пародонтита. В исследуемой группе с состоянием пародонта в стадии стабилизации находилось 24 человека. Это группа с заявленными исследуемыми шинами. И группа с иинами известными традиционными- в количестве 30 человек в группе. 
Результаты. При проведении исследования установлено, что через 18 месяцев значения показателя ИГ для больных без дефектов зубного ряда в группе контроля улучшилось, в среднем, на 60,9土2,1\%, а в группе исследования - лишь на 27,6士2,8\% (p<0,001).

За весь период исследования в группе без дефектов зубного ряда динамика развития признаков прочесса воспаления в исследуемой группе более сдержанная в сравнении с контролем.

Выводы. Проведенные исследования в группах паџиентов показали преимущество в применении новых иинируюших конструкций при использовании их при генерализованном пародонтите в стадии стабилизации перед традиционным шинированием по показателю ИГ. Улучшение в процентном соотношении составило за 18 месяиев $33,3 \pm 3,5 \%$.

Ключевые слова: генерализованный пародонтит в стадии стабилизации, показатели ИГ, интердентальное иинирование.

\author{
*P. V. Ishchenko, A. V. Borisenko
}

*Donetsk National Medical University of the Ministry of Health of UkraineNational Medical University named after. O.O. Bogomolets

\title{
ANALYSIS OF THE RESULTS OF APPLICATION OF THE DECLARED AND TRADI- TIONAL NON-REMOVABLE TREADING ORTHOPEDIC CONSTRUCTIONS IN PA- TIENTS WITHOUT DENTAL DEFECT, HAVING GENERALIZED PERIODONTITIS IN THE STABILIZATION STAGE ON THE INDICATOR OF IH
}

Topicality. The problem of periodontal diseases is a large percentage of dental diseases, which encourages doctors and practitioners of dentists to more actively engage in this pathology. Us for the treatment of generalized periodontitis by the orthopedic component proposed claimed interdental tires, which were used in the orthopedic treatment of patients with this pathology, along with traditional splinting.

objective. To find out clinically which of the tires used in the study are more physiological for provoked periodontal injury in the area of their responsibility by IH.

Materials and methods. This clinical study was conducted in a group of 54 patients with generalized periodontitis, undergoing stabilization. Previously, they had undergone comprehensive treatment for generalized periodontitis. In the study group with periodontal condition, there were 24 people in the stabilization stage. This is the group with the claimed test tires. And the group with the famous traditional tires - 30 people in the group.

Results. The study found that after 18 months, the value of the index of hygiene (IH) for patients without defects in the dental row in the control group improved, on average, by $60.9 \pm 2.1 \%$, and in the study group - only by 27, $6 \pm 2.8$ $\%(p<0.001)$.

For the entire period of study in the group without defects of the dentition, the dynamics of the development of signs of the process of inflammation in the study group is more restrained compared to the control, which indicates the feasibility of using the claimed structures in this group.

Conclusions. Studies in patient groups have found an advantage in the use of new splinting structures when applied to generalized periodontitis in the stabilization stage over traditional splinting in the case of IH. Percentage improvement in the 18 months was $33.3 \pm 3.5 \%$.

Keywords: generalized periodontitis in the stage of stabilization, $I H$, interdental splinting.

Актуальність. Проблема захворювань пародонту займає великий відсоток серед стоматологічних захворювань,що спонукає лікарів науковців та стоматологів практиків більш активно займатися даною патологією $[1,2]$. Ортопедичне втручання як одна із сторін комплексного підходу в лікуванні враженого пародонту дуже важлива на тлі функціонального відновлення цілосності зубного ряду у пацієнтів без дефектів зубного ряду 3 генералізованим пародонтитом у стадії стабілізації [3].

Нами для лікування генералізованого пародонтиту з боку ортопедичної складової запропоновані заявлені інтердентальні шини $[4,5]$, які використовувались при ортопедичному лікуванні пацієнтів 3 даною патологією поряд 3 традийійним шинуванням.

Mema. З'ясувати клінічно, які з використаних у дослідженні шин більш фізіологічні для спровокованого пародонту пацієнтів у зоні їх відповідальності за допомогою показника IГ.

Матеріали та методи. Дане клінічне дослідження проведене на групі з 54 хворих генералізованим пародонтитом, у стадії стабілізації. Попередньо їм було проведено комплексне лікування генералізованого пародонтита. У досліджуваній групі зі станом пародонта в стадії стабілізації перебувало 24 людини. Це група із заявленими досліджуваними шинами. I група із шинами відомими традиційними - у кількості 30 
людей у групі.

При дослідженні заявлених шин застосовувалися незнімні конструкції для зубних рядів без дефектів: ланцюгова всебічна (пат.72812), і якщо зуби були депульповані - то ланцюгова всебічна для депульпованих зубів(пат.79037). Шини відрізняються тільки за способом фіксації. У контрольній групі пацієнтів були використані наступні шини: коронкова паяна й суцільнолиті коронкоBi.

Розподіл хворих за віком і діагнозом захворювання в обох групах було ідентичним і порівнянним.

Отримані результати. Проведений аналіз результатів за індексом гігієни (IГ) дав наступні показники(таб.).

\section{Група паціснтів без дефектів зубного ряду.}

Таблиця

\begin{tabular}{|l|c|c|c|c|}
\hline \multirow{2}{*}{ Група } & \multicolumn{4}{|c|}{$\pm \mathrm{m}$} \\
\cline { 2 - 5 } & До лікування & 6 місяців & 12 місяців & 18 місяців \\
\hline Контроль (n=30) & $1,38 \pm 0,03$ & $1,65 \pm 0,04$ & $1,95 \pm 0,03$ & $2,22 \pm 0,03$ \\
\hline Дослідження (n=24) & $1,23 \pm 0,07$ & $1,36 \pm 0,08$ & $1,45 \pm 0,07$ & $1,57 \pm 0,07$ \\
\hline $\begin{array}{l}\text { Рівень значимості відмін- } \\
\text { ності між групами, } \mathrm{p}\end{array}$ & $>0,05$ & $<0,001^{*}$ & $<0,001^{*}$ & $<0,001^{*}$ \\
\hline
\end{tabular}

При проведенні аналізу встановлено, що до проведення лікування середнє значення індексу гігієни (ІГ) для хворих без дефектів зубного ряду в групі контролю $(1,38 \pm 0,03)$ і групі дослідження $(1,23 \pm 0,07)$ статистично значимо не відрізняється $(\mathrm{p}>0,05)$. Через 6 місяців після закінчення лікування також виявлено статистично значиму різницю $(\mathrm{p}<0,001)$ середнього значення Індекс гігієни (ІГ) для хворих без дефектів зубного ряду: у групі контролю $(1,65 \pm 0,04)$ і групі дослідження $(1,36 \pm 0,08)$. Через 12 місяців після закінчення лікування середнє значення Індекс гігієни (IГ) у групі контролю $(1,95 \pm 0,03)$ було статистично значимо ( $<0,001)$ вище, чим у групі дослідження $(1,45 \pm 0,07)$. Також виявлені відмінності $(\mathrm{p}<0,001)$ середнього значення індекса гігієни (IГ) і через 18 місяців після закінчення лікування: у групі контролю $(2,22 \pm 0,03)$ і групі дослідження $(1,57 \pm 0,07)$.

У групі пацієнтів без дефектів зубного ряду при дослідженні заявлених конструкцій перевага в стримуванні динаміки прояву запального процесу в порівнянні 3 контрольною групою, де використовувалися традиційні ортопедичні конструкції. Відмінності від значень групи контролю виявлені у всіх строках дослідження $(\mathrm{p}<0,05)$. Динаміка росту запального процесу в досліджуваній групі становить за всі місяці спостереження 0,34 одиниці, а в контрольній 0,84 одиниці приросту.

Обговорення результатів дослідження. Для виявлення лінійного тренда був використаний дисперсійний аналіз для повторних вимірів (використане логарифмічне перетворення), виявлене підвищення індексу гігієни (ІГ) згодом у групі контролю $(\mathrm{p}<0,001)$ і в групі дослідження $(\mathrm{p}<0,001)$.

При проведенні аналізу встановлено, що через 18 місяців значення індексу гігієни (ІГ) для хворих без дефектів зубного ряду в групі контролю покращилось, у середньому, на $60,9 \pm 2,1 \%$,

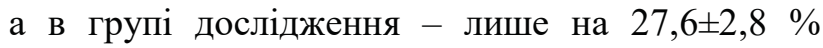
$(p<0,001)$.

За весь період дослідження в групі без дефектів зубного ряду динаміка розвитку ознак процесу запалення в досліджуваній групі більш стримана в порівнянні $з$ контролем, що говорить про доцільність застосування заявлених конструкцій у даній групі.

Висновки. За результатами проведеної роботи виявлено перевагу запропонованих інтердентальних шин при шинуванні зубного ряду у хворих на генералізований пародонтит у стадії стабілізації за показником ІГ. Поліпшення у відсотковому співвідношенні склало за 18 місяців $33,3 \pm 3,5 \%$.

\section{Список літератури}

1. Борисенко А.В. Заболевания пародонта / Борисенко А.В. - К.: «Медицина», 2013. - 456 с.

2. Данилевский Н.Ф. Заболевания пародонта / Н.Ф. Данилевский, А.В. Борисенко. - К.: Здоров'я, 2000. - 462 c.

3. Копейкин В.Н. Ортопедическое лечение заболеваний пародонта / Копейкин В.Н. - М.:«Триада-Х», 1998. - 176 c.

4. Іщенко П.В. Зубна шина / Іщенко П.В., Кльомін В.А., Хондошко М.В. // Деклараційний патент на корисну модель № 72812А61C8/02, заявлено 05.03.2012, опубліковано 27.08.2012. Бюл. №16.

5. Іщенко П.В. Зубна шина / Іщенко П.В., Кльомін В.А., Кашанський I.В., Ларічева Т.С. // Деклараційний патент на корисну модель № 79037А61С8/02 
заявлено 01.10.2012, опубліковано10.04.2013. Бюл. №7.

\section{REFERENCES}

1. Borisenko A.V. Zabolevaniya parodonta [Periodontal disease]. K.: «Meditsina», 2013; 456.

2. Danilevskiy N.F., Borisenko A.V. Zabolevaniya parodonta [Periodontal disease]. K.: Zdorov'ja; 2000:462.

3. Kopeykin V.N. Ortopedicheskoe lechenie zabolevaniy parodonta [Orthopedic treatment of periodontal diseases]. M.:«Triada-Kh»; 1998:176.
4. Ishhenko P.V. Kl'omin V.A., Hondoshko M.V. Zubna shyna [Dental splint]. Declarative patent for utility model No. 72812A61S8 / 02, filed 05.03.2012, published 27.08.2012. Bull. No. 16.

5. Ishhenko P.V. Kl'omin V.A., Kashans'kyj I.V., Laricheva T.S. Zubna shyna [Dental splint]. Declarative patent for utility model no. 79037A61S8 / 02 declared 01.10.2012, opublikovano10. 04. 2013. Bull. No. 7.

Надійшла 23.01.19 